\title{
Management of cow's milk protein allergy in primary care
}

\author{
Dinkar Bakshi ${ }^{*}$, lan Pollock ${ }^{2}$ \\ From Food Allergy and Anaphylaxis Meeting 2011 \\ Venice, Italy. 17-19 February 2011
}

\section{Background}

The incidence of Cow's Milk Protein Allergy ( CMPA ) is increasing in the United Kingdom. However, many practitioners in primary care are unsure about its diagnosis and management. There is usually a lag period of a few months, between the first presentation of children with CMPA to their General Practitioner ( GP ), and referral to an Allergist. Enfield area comprises a middleclass, and relatively affluent population of London.

\section{Aim}

To identify the factors that influence CMPA primary care management and referral practice, in Enfield area in London.

\section{Methods}

A web-based questionnaire was completed by 46 General Practitioners in Enfield area, in January, 2010.

\section{Results}

$87 \%$ of the respondents felt that children with suspected CMPA, should be seen by an Allergist within 4 weeks from the date of referral. $54.3 \%$ of the GPs said that they referred children to a Paediatric Allergist, after a trial of extensively hydrolysed or aminoacid formula milk. The most popular milk substitutes in primary care in Enfield are Nutramigen (60.9\%), Soya milk (52.2\%), Neocate (47.8\%) and Peptijunior (17.4\%). 82.6\% GPs said they prescribe Epipen (Adrenaline autoinjector) for life threatening allergic symptoms. With regards to referral to a Paediatric Dietitian, 34.8\% GPs said they refer less than 25\% cases of CMPA, whereas $43.5 \%$ GPs refer over $75 \%$ children with CMPA. GPs got information about management of CMPA primarily from

${ }^{1}$ Homerton University Hospital, London, UK

Full list of author information is available at the end of the article

Paediatricians (71.7\%), while a significant number also accessed journals (52.2\%) and the internet (50.0\%).

\section{Conclusion}

The management of CMPA in primary care in Enfield is not consistent, and dependent upon the individual GPs. We have initiated the formulation and dissemination of a local guideline, to enable practitioners in primary care to refer children with suspected CMPA to the Allergy clinic.

\section{Author details}

${ }^{1}$ Homerton University Hospital, London, UK. ${ }^{2}$ Chase Farm Hospital, Paediatrics, London, UK.

Published: 12 August 2011

doi:10.1186/2045-7022-1-S1-P40

Cite this article as: Bakshi and Pollock: Management of cow's milk protein allergy in primary care. Clinical and Translational Allergy 20111 (Suppl 1):P40.

Submit your next manuscript to BioMed Central and take full advantage of:

- Convenient online submission

- Thorough peer review

- No space constraints or color figure charges

- Immediate publication on acceptance

- Inclusion in PubMed, CAS, Scopus and Google Scholar

- Research which is freely available for redistribution 